\title{
Consumption of addictive goods in Russian regions and its impact on the quality of human capital
}

\author{
R.Yu. Skokov $₫$, O.V. Brizhak ${ }^{2,3}$ \\ ${ }^{1}$ Volgograd State Agrarian University, Volgograd, Russia; e-mail: rskokov@mail.ru \\ ${ }^{2}$ State University of Management, Moscow, Russia \\ ${ }^{3}$ Kuban State Technological University, Krasnodar, Russia
}

\begin{abstract}
Research relevance. Consumption of addictive goods and its impact on the human capital is widely discussed in contemporary research literature, not only on the micro- and macro- but also on the meso-level. At the present stage of the ongoing transformations we are prompted to reassess current approaches to this problem and to re-evaluate its public significance; moreover, practical application of available research outcomes should also be reconsidered. In Russia, consumption of addictive goods is subject to significant regional variations determined by socio-economic and other factors. Research aim. The study is aimed at investigating the impact of consumption of addictive goods (alcohol) on the quality of Russian consumers' human capital and at building a system of indicators to estimate this impact. Data and methods. The study uses the methods of comparative analysis, expert estimation, ranking, and economic-statistical analysis, it also proposes a spatial approach to problems associated with regional variations in human capital of consumers of addictive goods. The study relies on the Russian and international research evidence; the data of the Federal State Statistics Service and its regional offices; expert estimates and the authors' own calculations. Results. The study demonstrates the connection between consumption of addictive goods and consumers' human capital. It also describes a system of statistical indicators that can be used for estimating the impact of alcohol consumption on human capital and the criteria such indicators should meet. Based on the proposed indicator set, the study analyzes and compares the trends in human capital deterioration on the regional and national levels. As a result of cross-regional analysis, regions with the highest and lowest figures of human capital deterioration are identified. Conclusions. As their addiction progresses, alcohol consumers face an increasing devaluation of their human capital. This parameter varies significantly across Russian regions due to a range of climatic, regional, and socio-economic factors, which should be taken into account when devising and implementing regional alcohol policies. The existing system of statistical observations uses a limited set of indicators that needs to be expanded to allow for a more comprehensive cross-regional analysis.
\end{abstract}

\section{KEYWORDS}

addictive goods, consumer behaviour, theory of consumer demand, government regulation, human capital, regional variation, regional policy

\section{ACKNOWLEDGMENTS}

The research was supported by the Russian Foundation for Basic Research and Volgograd Region Administration (research project № 19-410-340006, r_a).

\section{FOR CITATION}

Skokov, R.Yu., \& Brizhak, O.V. (2020). Consumption of addictive goods in Russian regions and its impact on the quality of human capital. R-economy, 6(1), 50-60. doi: 10.15826/recon.2020.6.1.005

\section{Влияние аддиктивных товаров на качество человеческого капитала потребителей: региональный аспект}

\author{
Р.Ю. Скоков ${ }^{1} \bowtie$, О.В. Брижак ${ }^{2,3}$ \\ ${ }^{1}$ Волгоградский государственный аграрный университет, Волгоград, Poсcия; e-mail: rskokov@mail.ru \\ ${ }^{2}$ Государственный университет управления, Москва, Россия \\ ${ }^{3}$ Кубанский государственный технологический университет, Краснодар, Россия
}

\section{АННОТАЦИЯ}

Актуальность. Разработка научной проблемы формирования человеческого капитала потребителей аддиктивных товаров приобретает все большую актуальность не только на микро- и макроуровне, но и на мезоуровне. Современный этап трансформационных процессов заставляет переосмысливать представления об указанной проблеме, ее общественной значимости, использовании прикладных результатов исследований. В российских условиях актуальность изучения территориальных аспектов дифференциации потребления аддиктивных товаров связана с высокой поляризацией соци-

\section{КЛЮЧЕВЫЕ СЛОВА}

аддиктивные товары, потребительское поведение, теория потребительского спроса, государственное регулирование, человеческий капитал, региональные различия, региональная политика 
ально-экономического положения регионов и многообразием факторов ее определяющих. Цель исследования. Выявить результаты влияния аддиктивных товаров на качество человеческого капитала потребителей в регионах России (на примере потребления алкогольной продукции) и сформировать систему показателей, определяющих тенденции указанного процесса. Данные и методы. В исследовании были использованы методы сравнительного анализа, экспертных оценок, ранжирования, методы экономико-статистического анализа. Предложен пространственный подход к исследованию проблем региональной дифференциации показателей человеческого капитала потребителей аддиктивных товаров. Информационную базу исследования составили результаты исследований отечественных и зарубежных экономистов потребления аддиктивных товаров; официальные данные Федеральной службы государственной статистики и ее территориальных органов, а также экспертные оценки и авторские расчеты. Результаты. Раскрыта связь между потреблением аддиктивных товаров и человеческим капиталом потребителя; обоснованы требования к показателям, которые целесообразно использовать для оценки влияния на человеческий капитал потребления алкоголя; с учетом данных требований предложена совокупность статистических показателей; проведена оценка динамики показателей деградации человеческого капитала на общероссийском уровне и межрегиональные сравнения. В ходе межрегиональных сравнений выделены регионы с наиболее высокими и наиболее низкими показателями деградации человеческого капитала. Выводы. Злоупотребление аддиктивными товарами сопровождается деградацией человеческого капитала индивида по мере роста зависимости. Уровень «деградации» человеческого капитала от потребления аддиктивных товаров в российских регионах значительно варьируется в силу многообразия климатических, религиозных, социально-экономических особенностей, которые необходимо учитывать при разработке и реализации дифференцированной антиалкогольной политики. Существующая система статистических наблюдений позволяет провести межрегиональные сравнения по ограниченному числу показателей и нуждается в совершенствовании.

\section{БЛАГОДАРНОСТИ}

Работа выполнена при поддержке Российского фонда фундаментальных исследований и Администрации Волгоградской области (исследовательский проект № 19-410-340006, p_a).

\section{ДЛЯ ЦИТИРОВАНИЯ}

Skokov, R.Yu., \& Brizhak, O.V. (2020). Consumption of addictive goods in Russian regions and its impact on the quality of human capital. R-economy, 6(1), 50-60. doi: $10.15826 /$ recon.2020.6.1.005

\section{Introduction}

Consumption of harmful addictive goods presents an interesting problem for researchers. G. Becker [1], G. Edwards [2], J. Gruber [3], J.V. Koch, and S. Group [4] devote considerable attention to consequences of addictive consumer behaviour, in particular the development of bad habits. The scale of the negative consequences of consumption of goods posing health risks and the rapid deterioration of consumers' human capital determine the practical relevance of research in this area. Consumption of addictive goods and its negative consequences are determined by a range of economic, social, psychological and other factors, which vary considerably across regions and countries. That being said, significant regional variations are observed in consumption patterns as well. In Russia, the level of consumption of addictive goods is quite high, although there has been a long-term downward trend. For example, in the commodity market, the retail turnover of alcoholic beverages and tobacco products fell from $19 \%$ in 1970 to $9 \%$ in 2015 [5; 6]. However, there are multifold regional differences in the consumption of these goods and in its negative effects.
In the light of the above, the purpose of this study is to describe the changes in the human capital of consumers of addictive goods in Russian regions by focusing on alcohol consumption.

The following research objectives would facilitate the achievement of this aim. First, we are going to characterize the existing approaches in Russian and international research to the choice of indicators for analysis of the deterioration of human capital due to consumption of addictive goods. Second, we are going to develop a system of indicators to estimate the impact of alcohol consumption on consumers' human capital and apply these indicators for cross-regional comparative analysis (our findings can be used for devising national and regional alcohol policies). Finally, we will rank Russian regions depending on the levels of deterioration of the human capital caused by alcohol consumption.

\section{Literature review}

Economic analysis of addictive consumer behaviour relies on a range of methodological and theoretical frameworks, such as neoclassical economics, institutionalism and neoinstitutiona- 
lism. G. Becker and K. Murphy's model of 'rational addiction' [7] laid the foundation for a large number of theoretical and practical studies, such as A.Maynard and A.Wagstaf's study of government intervention into the illicit drug markets in the UK [8]; F.Chaloupka and K.Warner's study of the myopic behaviour of consumers underestimating the risks of smoking [9]; D. Gieringer's study of cannabis legalization [10]; mathematical analysis justifying controlled partial legalization of currently illicit drugs and the analysis of the data on cocaine and marijuana demand among the youth by F. Chaloupka, M. Grossman and J. Tauras [11]; liquor consumption analysis by B. Baltagi and J. Griffin [12]; K. Wangen's discussion of the problems arising in the course of econometric implementation of rational addiction theory [13]; models of alcohol consumer behaviour in different stages - 'periodic bingers', 'in recovery', and 'detox' [14]; B.Gordon and B.Sun's dynamic model of rational addiction [15]; and D. Evans's study of the socio-economic impacts of marijuana legalization [16]. In Russia, there are comparatively few studies that use economic models of addictive behaviour with the exception of the research published by M. Levin [17], K. Filippov [18], M. Ponomareva [19] and L. Timofeev [20].

Although, according to the classical rational addiction theory, consumers of addictive goods are expected to behave as rational utility maximizers, in reality their behaviour tends to be more complex and inconsistent as they may lose sight of their budget constraints and ignore the future consequences ('conscious' lifetime utility maximization leading to the lethal outcome), which requires further analysis.

International research of the alcohol market, which is a typical addictive market, distinguishes between two types of consumption: the northern type characterized by heavy drinking of strong liquors while the southern type, by the prevalence of wine and beer consumed in relatively small doses $^{1}[2 ; 15 ; 16]$. There are also different forms of state regulation of addictive markets such as state monopolies over retailing alcoholic beverages or monopolies on manufacturing and distribution of alcohol; the use of state licensing to control the competition on the alcohol market [21-23]. In both cases, state plays a key role in this market.

Economic forecast «The World in 2050» (2015). Joint Stock Company «PricewaterhouseCoopers Audit». (In Russ.) Retrieved from: http://www.pwc.ru/ru/press-releases/2015/ economic forecast 2050.html
Despite the diversity of consumption types and market regulation models as well as considerable regional disparities in socio-economic development, Russia continues to implement a unified federal alcohol policy.

\section{Indicators to measure the alcohol-related deterioration of consumers' human capital}

Personal consumption is crucial for the formation of human capital. Consumption of vital goods ensures simple reproduction of human capital while consumption of such commodities as education, science, and medicine provides expanded reproduction of human capital. The human capital of an employee who has begun to consume addictive products in abnormal doses will decline. For a woman, it takes on average about 3-5 years to develop an addiction; for men, 8-9 years of regular consumption of alcoholic beverages [24]. According to the Labour Code of Russia, an employment contract can be terminated by the employer if an employee shows up to work in the state of alcohol, drug or toxic intoxication [25].

Top executives of enterprises consider alcohol abuse as the third most important health issue facing their employees (after smoking and cardiovascular diseases). Most top executives (74\%) believe that alcohol abuse has a negative impact on their companies' performance [26]. Alcohol addicts are likely to lose a stable source of income and engage in low-paid menial work. The share of unskilled labor in GDP of developed and developing countries, including Russia, is shrinking, and in technologically advanced countries it is already vanishingly small [26], so the human capital of unskilled workers will increase together with the growth rate of the real gross domestic product of the world economy or may remain unchanged.

C. Loveland-Cherry brought to light the inverse relationship between academic performance and alcohol consumption among students [27]. They also showed a positive relationship between increasing alcohol consumption, on the one hand, and low academic performance and school absenteeism, on the other. P. Cook and M. Moore found that heavy drinking in high school (consumption of alcohol twice a week) reduces the average number of years of schooling completed after high school by 2-3 years [28]. V. Kim and S. Roschin demonstrated that alcohol abuse among males has a significant negative effect on employment op- 
portunities, wage level and the number of hours worked [6].

The $\mathrm{WHO}^{2}$, G. Edwards [2], E. Andreev and I. Zbarskaya [29] show that consumption of addictive goods has a negative impact on people's physical and mental health and increases their vulnerability to various illnesses. V. Grigoryev and Y. Zeitlin explain the increase in new HIV diagnoses since 1996 in Russia by the spreading substance use and abuse [30]. Alcohol plays an important role in Russian 'supermortality' deaths from such causes as homicide, suicide, road accidents, injuries, fatalities and so on [31]. In Russia, $61 \%$ of deaths from external causes are alcohol-related ${ }^{3}$. According to D. English, in developed countries, $34 \%$ of deaths from drowning, falls and road injuries as well as $47 \%$ of homicides, $41 \%$ of suicides and $44 \%$ fire deaths were attributable to alcohol consumption ${ }^{4}$.

The influence of addictive goods on life expectancy was discussed by K. Danishevsky [32], A. Korotaev and D. Khalturina [33], A. Nemtsov and A. Podlazov [26; 34-35]. It is shown that an increase in effective consumption of 1 litre per person a year lowers the average life expectancy for men by $0,84 \pm 0,04$ years and for women, by $0,32 \pm 0,03$ years [34].

There is a broad range of indicators reflecting different aspects of alcohol-related human capital deterioration, which makes systematization of these indicators a problem in its own right $[36 ; 37]$. In the context of our study, however, the main challenge is to select the indicators suitable for estimating the influence of alcohol consumption on human capital and for making cross-regional comparisons. In our view, these indicators should meet the following criteria:

- they should be among the indicators used for regular monitoring by the official statistical and other state agencies or by expert organizations;

2 WHO. Global Status Report on Alcohol. (2004). Country profile. Retrieved from: http://whqlibdoc.who.int/publications /2004/9241562722 (425KB).pdf

${ }^{3}$ Report of the Public Chamber of the Russian Federation of May 13, 2009 'Alcohol abuse in the Russian Federation: socio-economic consequences and countermeasures'. Public Chamber of the Russian Federation. (In Russ.) Retrieved from: http://www.oprf.ru/files/dokladalko.pdf

4 The average monthly nominal wages of employees of organizations of the Russian Federation in 1991-2016. Federal State Statistics Service. (In Russ.) Retrieved from: http://www.gks.ru/wps/wcm/connect/rosstat main/rosstat/ $\underline{\mathrm{ru} / \mathrm{statistics} / \text { wages/ }}$
- they should include regional and federallevel data;

- they should reflect direct rather than indirect influence of alcohol consumption on the quality of human capital.

It is necessary to have access to long-term statistical observations in order to detect random variations, make forecasts, and use methods of economic-statistical analysis and modelling to formulate evidence-based guidelines and recommendations. Availability of the regionallevel data, in its turn, enables us to draw crossregional comparisons and bring to light the role of different factors in specific regions in shaping alcohol consumption patterns. As for the third requirement, it helps us eliminate ambiguity in the interpretations of the results. Table 1 summarizes the indicators we are going to use in our analysis.

Indicators of alcohol-related deterioration of human capital in Russian regions

\begin{tabular}{|l|c|}
\hline \multicolumn{1}{|c|}{ Indicator } & Notation \\
\hline $\begin{array}{l}\text { Number of deaths from alcohol poisoning per } \\
100,000 \text { people, ths people }\end{array}$ & $\mathrm{HC}_{1}$ \\
\hline $\begin{array}{l}\text { Number of alcohol-related crimes per } \\
100,000 \text { people, units per year }\end{array}$ & $\mathrm{HC}_{2}$ \\
\hline $\begin{array}{l}\text { Household consumption expenditures on } \\
\text { alcoholic beverages, \% of aggregate consumer } \\
\text { expenditures }\end{array}$ & $\mathrm{HC}_{3}$ \\
\hline $\begin{array}{l}\text { Number of newly diagnosed cases of alco- } \\
\text { holism and alcohol-induced psychosis per } \\
100,000 \text { people }\end{array}$ & $\mathrm{HC}_{4}$ \\
\hline $\begin{array}{l}\text { Number of cases of recurrent alcoholism and } \\
\text { alcohol-induced psychosis per 100,000 people }\end{array}$ & $\mathrm{HC}_{5}$ \\
\hline Percentage of adult non-drinkers, \% & $\mathrm{HC}_{6}$ \\
\hline
\end{tabular}

Indicator $\mathrm{HC}_{1}$ is calculated by the Federal State Statistics Service (Rosstat) as a ratio of the number of alcohol-related deaths to mid-year population.

Indicator $\mathrm{HC}_{2}$ is calculated as a ratio of the number of alcohol-related crimes (from the number of investigated crimes) to mid-year population. For this indicator we used the data from Form '3-EGS' of the Federal Statistical Monitoring 'Data on Registered, Solved and Unsolved Crimes', based on the reports of the information centres of regional law enforcement agencies.

Indicator $\mathrm{HC}_{3}$ relies on the data of the household sample surveys conducted by Rosstat.

Indicator $\mathrm{HC}_{4}$ is computed by Rosstat as an integer of the number of newly diagnosed cases of alcoholism and alcohol-induced psychosis and 
the end of year population by using the following formula:

$$
\mathrm{HC}_{4}=a / b \cdot 100000 \text {, }
$$

where $a$ is the number of newly diagnosed cases of alcohol and alcohol-induced psychosis and $b$ is the end of year population;

Indicator $\mathrm{HC}_{5}$ is the number of cases of recurrent alcoholism and alcohol-induced psychosis per 100,000 people calculated by Rosstat the same way as indicator $\mathrm{HC}_{4}$.

Indicator $\mathrm{HC}_{6}$ is based on the data provided by the Russian Public Opinion Research Center (VTsIOM). Their telephone survey covered 1,600 respondents aged 18 or older. The survey was conducted by using stratified dual-frame random sample based on a complete list of landline and mobile phone numbers operating in Russia. So far VTsIOM has provided no geographic breakouts of their survey data for Russian regions.

\section{Analysis of the impact of alcohol consumption on human capital (national and regional aspects)}

The above-described indicators were tested and found suitable for analyzing the impact of alcohol consumption on human capital in Russia on the regional and national levels. Table 2 illustrates the level of deterioration of human capital associated with alcohol consumption in Russia.

Overall, we can observe downward trends in the indicators characterizing the alcohol-relatead deterioration of human capital in Russia. The most remarkable trend is an almost 30\% decrease in the number of deaths from alcohol poisoning. Interestingly, the share of alcohol in consumer expenditures of households has remained virtually unchanged. There is a gra- dual decrease in the number of alcohol-related crimes as well as in the number of people suffering from alcoholism and related psychiatric disorders. Nevertheless, these figures are still quite high in Russia.

At the next stage of our analysis, we compared these figures in different Russian regions by using the ranking method. First, each region was ranked for each of the indicators $\mathrm{H}_{1}-\mathrm{H}_{5}$ Then, the total score for each region was calculated by summing its positions in each of the indicators. The regions were ranked (R) from the most successful (top of the ranking) to those lagging behind (bottom of the ranking). The less the region scored, the more successful it was and the higher was its position in the ranking. Since the information for some regions was incomplete, we used the data for 2015, which proved to be sufficient for our calculations and we could systematize the data for all the chosen indicators. Indicators $\mathrm{HC}_{3}$ and $\mathrm{HC}_{6}$ were excluded due to the lack of the necessary regional data [37]. Table 3 summarizes the results of our analysis.

The top of the ranking is occupied by such regions as Ingushetia, Chechnya, Dagestan, St. Petersburg and Moscow cities, North Ossetia, Krasnodar region, Karachay-Cherkessia, Belgorod and Stavropol regions. Religion is an important factor shaping consumer behavior in Muslim-majority regions: Ingushetia has the lowest rates of deaths caused by alcohol poisoning, alcoholism and alcohol-induced psychic disorders; Chechnya has the lowest level of alcohol-related crimes; Tatarstan ranks $12^{\text {th }}$, after Kabardino-Balkaria. Surprisingly, however, religion appears to be less significant in Bashkortostan, which has the $30^{\text {th }}$ position in our ranking.

Table 2

Deterioration of human capital in Russia caused by alcohol consumption

\begin{tabular}{|c|c|c|c|c|c|}
\hline Indicator & 2014 & 2015 & 2016 & 2017 & 2018 \\
\hline $\begin{array}{l}\text { Number of deaths from alcohol poisoning per } 100,000 \text { people, } \\
\text { ths people }\end{array}$ & 10.71 & 10.41 & 9.56 & 8.36 & 7.5 \\
\hline $\begin{array}{l}\text { Number of alcohol-related crimes per } 100,000 \text { people, units } \\
\text { per year }\end{array}$ & 241.86 & 273.92 & 300.09 & 257.43 & 239.46 \\
\hline $\begin{array}{l}\text { Household consumption expenditures on alcoholic beverages, } \\
\% \text { of aggregate consumer expenditures }\end{array}$ & 1.7 & 1.8 & 1.7 & 1.6 & 1.6 \\
\hline $\begin{array}{l}\text { Number of newly diagnosed cases of alcoholism and alco- } \\
\text { hol-induced psychosis per } 100,000 \text { people }\end{array}$ & 74.6 & 70.9 & 64.9 & $\mathrm{n} / \mathrm{a}$ & $\mathrm{n} / \mathrm{a}$ \\
\hline $\begin{array}{l}\text { Number of cases of recurrent alcoholism and alcohol-induced } \\
\text { psychosis per } 100,000 \text { people }\end{array}$ & 1155.4 & 1076.2 & 984 & $\mathrm{n} / \mathrm{a}$ & $\mathrm{n} / \mathrm{a}$ \\
\hline Percentage of adult non-drinkers, $\%$ & $\mathrm{n} / \mathrm{a}$ & $\mathrm{n} / \mathrm{a}$ & $\mathrm{n} / \mathrm{a}$ & 39 & 40 \\
\hline
\end{tabular}

Compiled by the authors by using the data of the Unified Interdepartmental Statistical Information System. Retrieved from: https://gks.ru/emiss (Accessed: 11.04.2020). 
Ranking of Russian regions in terms of alcohol-related deterioration of human capital

\begin{tabular}{|c|c|c|c|c|c|c|}
\hline Regions & $\mathrm{RHC}_{1}$ & $\mathrm{RHC}_{2}$ & $\mathrm{RCH}_{4}$ & $\mathrm{RCH}_{5}$ & $\Sigma \mathrm{RCH}$ & R $\Sigma$ RCH \\
\hline \multicolumn{7}{|c|}{ Central Federal District } \\
\hline Belgorod region & 9 & 15 & 18 & 18 & 60 & 9 \\
\hline Bryansk region & 47 & 47 & 64 & 81 & 239 & 61 \\
\hline Vladimir region & 79 & 52 & 42 & 74 & 247 & 65 \\
\hline Voronezh region & 67 & 18 & 70 & 58 & 213 & 49 \\
\hline Ivanovo region & 85 & 37 & 68 & 86 & 276 & 72 \\
\hline Kaluga region & 57 & 33 & 41 & 38 & 169 & 35 \\
\hline Kostroma region & 48 & 46 & 43 & 78 & 215 & 51 \\
\hline Kursk region & 24 & 45 & 62 & 52 & 183 & 41 \\
\hline Lipetsk region & 80 & 22 & 48 & 75 & 225 & 56 \\
\hline Moscow region & 49 & 11 & 19 & 40 & 119 & 21 \\
\hline Orel region & 50 & 32 & 60 & 67 & 209 & 47 \\
\hline Ryazan region & 33 & 19 & 32 & 66 & 150 & 28 \\
\hline Smolensk region & 54 & 41 & 50 & 65 & 210 & 48 \\
\hline Tambov region & 62 & 26 & 24 & 80 & 192 & 44 \\
\hline Tver region & 72 & 43 & 28 & 71 & 214 & 50 \\
\hline Tula region & 83 & 17 & 47 & 72 & 219 & 53 \\
\hline Yaroslavl region & 82 & 27 & 49 & 43 & 201 & 45 \\
\hline City of Moscow & 12 & 6 & 8 & 6 & 32 & 5 \\
\hline \multicolumn{7}{|c|}{ North-Western Federal District } \\
\hline Republic of Karelia & 61 & 72 & 81 & 77 & 291 & 74 \\
\hline Republic of Komi & 84 & 86 & 55 & 44 & 269 & 69 \\
\hline Arkhangelsk region & 73 & 67 & 46 & 57 & 243 & 63 \\
\hline Nenets Autonomous District & 53 & 70 & 82 & 68 & 273 & 70 \\
\hline Arkhangelsk region without autonomous districts & 75 & 66 & 46 & 56 & 243 & 63 \\
\hline Vologda region & 37 & 76 & 30 & 32 & 175 & 38 \\
\hline Kaliningrad region & 76 & 35 & 44 & 33 & 188 & 42 \\
\hline Leningrad region & 70 & 16 & 10 & 17 & 113 & 19 \\
\hline Murmansk region & 56 & 42 & 59 & 15 & 172 & 36 \\
\hline Novgorod region & 86 & 54 & 54 & 79 & 273 & 70 \\
\hline Pskov region & 51 & 40 & 61 & 64 & 216 & 52 \\
\hline City of St. Petersburg & 18 & 4 & 4 & 4 & 30 & 4 \\
\hline \multicolumn{7}{|c|}{ Southern Federal District } \\
\hline Republic of Adygea & 46 & 21 & 25 & 73 & 165 & 33 \\
\hline Republic of Kalmykia & 22 & 20 & 13 & 31 & 86 & 14 \\
\hline Republic of Crimea & 38 & 12 & 67 & 36 & 153 & 29 \\
\hline Krasnodar region & 11 & 14 & 9 & 8 & 42 & 7 \\
\hline Astrakhan region & 23 & 30 & 15 & 30 & 98 & 16 \\
\hline Volgograd region & 28 & 31 & 27 & 19 & 105 & 17 \\
\hline Rostov region & 5 & 9 & 12 & 34 & 60 & 9 \\
\hline City of Sevastopol & 19 & 10 & 75 & 16 & 120 & 22 \\
\hline \multicolumn{7}{|c|}{ North Caucasian Federal District } \\
\hline Republic of Dagestan & 3 & 3 & 3 & 3 & 12 & 3 \\
\hline Republic of Ingushetia & 1 & 2 & 1 & 1 & 5 & 1 \\
\hline Kabardino-Balkarian Republic & 16 & 7 & 29 & 12 & 64 & 11 \\
\hline Karachay-Cherkess Republic & 7 & 8 & 7 & 29 & 51 & 8 \\
\hline Republic of North Ossetia & 4 & 5 & 17 & 7 & 33 & 6 \\
\hline Chechen Republic & 2 & 1 & 2 & 2 & 7 & 2 \\
\hline Stavropol region & 21 & 13 & 6 & 23 & 63 & 10 \\
\hline
\end{tabular}


End of Table 3

\begin{tabular}{|c|c|c|c|c|c|c|}
\hline Regions & \begin{tabular}{l|l} 
RHC $_{1}$ \\
\end{tabular} & $\mathrm{RHC}_{2}$ & $\mathbf{R C H}_{4}$ & $\mathbf{R C H}_{5}$ & $\Sigma \mathrm{RCH}$ & R $\Sigma$ RCH \\
\hline \multicolumn{7}{|c|}{ Volga Federal District } \\
\hline Republic of Bashkortostan & 26 & 56 & 38 & 35 & 155 & 30 \\
\hline Mari El Republic & 65 & 49 & 56 & 70 & 240 & 62 \\
\hline Republic of Mordovia & 42 & 24 & 45 & 46 & 157 & 31 \\
\hline Republic of Tatarstan & 20 & 23 & 22 & 14 & 79 & 12 \\
\hline Udmurt Republic & 78 & 78 & 66 & 53 & 275 & 71 \\
\hline Chuvash Republic & 52 & 51 & 69 & 76 & 248 & 66 \\
\hline Perm region & 68 & 73 & 74 & 63 & 278 & 73 \\
\hline Kirov region & 43 & 79 & 31 & 60 & 213 & 49 \\
\hline Nizhny Novgorod region & 71 & 29 & 33 & 82 & 215 & 51 \\
\hline Orenburg region & 39 & 53 & 76 & 22 & 190 & 43 \\
\hline Penza region & 41 & 34 & 77 & 54 & 206 & 46 \\
\hline Samara region & 6 & 28 & 23 & 24 & 81 & 13 \\
\hline Saratov region & 29 & 25 & 35 & 50 & 139 & 24 \\
\hline Ulyanovsk region & 58 & 44 & 72 & 55 & 229 & 57 \\
\hline \multicolumn{7}{|c|}{ Ural Federal District } \\
\hline Kurgan region & 77 & 85 & 63 & 42 & 267 & 68 \\
\hline Sverdlovsk region & 60 & 58 & 40 & 9 & 167 & 34 \\
\hline Tyumen region & 15 & 62 & 34 & 27 & 138 & 23 \\
\hline Khanty-Mansiysk Autonomous District (Yugra) & 10 & 50 & 36 & 20 & 116 & 20 \\
\hline Yamalo-Nenetsk Autonomous District & 27 & 65 & 79 & 62 & 233 & 59 \\
\hline Tyumen region without autonomous districts & 14 & 71 & 34 & 26 & 145 & 27 \\
\hline Chelyabinsk region & 74 & 68 & 51 & 39 & 232 & 58 \\
\hline \multicolumn{7}{|c|}{ Siberian Federal District } \\
\hline Republic of Altai & 44 & 87 & 26 & 25 & 182 & 40 \\
\hline Republic of Buryatia & 69 & 84 & 16 & 11 & 180 & 39 \\
\hline Republic of Tyva & 32 & 81 & 5 & 45 & 163 & 32 \\
\hline Republic of Khakassia & 36 & 83 & 53 & 48 & 220 & 54 \\
\hline Altai region & 13 & 77 & 73 & 47 & 210 & 48 \\
\hline Zabaikalye region & 63 & 82 & 57 & 41 & 243 & 63 \\
\hline Krasnoyarsk region & 30 & 64 & 65 & 21 & 180 & 39 \\
\hline Irkutsk region & 31 & 59 & 71 & 49 & 210 & 48 \\
\hline Kemerovo region & 59 & 80 & 21 & 13 & 173 & 37 \\
\hline Novosibirsk region & 34 & 36 & 11 & 10 & 91 & 15 \\
\hline Omsk region & 64 & 38 & 14 & 28 & 144 & 26 \\
\hline Tomsk region & 25 & 55 & 20 & 5 & 105 & 18 \\
\hline \multicolumn{7}{|c|}{ Far Eastern Federal District } \\
\hline Republic of Sakha (Yakutia) & 35 & 60 & 84 & 59 & 238 & 60 \\
\hline Kamchatka region & 45 & 39 & 52 & 85 & 221 & 55 \\
\hline Primorye region & 8 & 57 & 39 & 37 & 141 & 25 \\
\hline Khabarovsk region & 17 & 61 & 80 & 61 & 219 & 53 \\
\hline Amur region & 66 & 69 & 58 & 51 & 244 & 64 \\
\hline Magadan region & 81 & 75 & 85 & 84 & 325 & 75 \\
\hline Sakhalin region & 40 & 63 & 83 & 83 & 269 & 69 \\
\hline Jewish Autonomous District & 55 & 48 & 78 & 69 & 250 & 67 \\
\hline Chukotka Autonomous District & 87 & 74 & 86 & 87 & 334 & 76 \\
\hline
\end{tabular}

Compiled by the authors by using the data of the Unified Interdepartmental Statistical Information System. Retrieved from: https://gks.ru/emiss (Accessed:12.02 2020). 
Regions of the North-Caucasian Federal District - Dagestan, Ingushetia, Kabardino-Balkaria, Karachay-Cherkessya, North Ossetia, Chechnya and Stavropol region - are in the top of the regions that drink the least alcohol. It may seem surprising that the cities St.Petersburg and Moscow, Krasnodar and Belgorod regions are also at the top despite their relatively high alcohol consumption levels. Their results can be explained by greater efficiency of regional health care and law enforcement agencies. The cities Moscow and St. Petersburg and Krasnodar region have comparatively low alcohol-related crime rates and fewer cases of alcohol-induced disorders and alcoholism. Another driver of these regions' performance is the higher income level, which means that their inhabitants can afford to consume more expensive and, therefore, less toxic alcohol.

The heaviest drinking regions are Chukotka Autonomous District, Karelia, Perm, Magadan and Ivanovo regions, Udmurtia, Nenets $\mathrm{Au}$ tonomous District, Novgorod region, the Komi Republic, Sakhalin and Kurgan regions, and Jewish Autonomous District. Chukotka Autonomous District and Magadan region have the highest rates of deaths due to alcohol poisoning, alcohol-related crime and the number of cases of alcoholism and alcohol-induced psychosis. Karelia has a high incidence of alcohol-related crime and high rates of alcoholism and alcohol-induced disorders. Perm region also has to struggle with high rates of alcohol-related crime and newly diagnosed cases of alcoholism and alcohol-induced psychosis. Ivanovo region has the highest rate of deaths caused by alcohol poisoning and also the largest number of cases of recurrent alcoholism and alcohol-induced psychosis. In Udmurtia and Kurgan region, there are high rates of deaths caused by alcohol poisoning and alcohol-related crimes. The level of the latter is also high in Nenets Autonomous District, which also suffers from a high incidence of alcoholism and alcohol-induced psychosis. In Novgorod region, the alcohol-related death rate is one of the highest in Russia (in this indicator, Novgorod region is preceded by $\mathrm{Chu}$ kotka Autonomous District) and a high rate of alcoholism (number of cases of recurrent alcoholism and alcohol-induced psychosis). The Republic of Komi has an extremely high level of alcohol-related violence and rate of deaths caused by alcohol poisoning. Both Sakhalin region and
Jewish Autonomous District have high rates of alcoholism (reflected by the two indicators - the number of newly diagnosed cases of alcoholism and alcohol-induced psychosis and the number of cases of recurrent alcoholism and alcohol-induced psychosis).

In this case, it is evident that the high level of deterioration of human capital is closely linked to the general state of economic depression in some regions and the low level of per capita income. Another important characteristic shared by the lagging regions is that they are located remotely from large economic centres.

\section{Conclusion}

The results of our study have lead us to the following conclusions:

1. As the addiction progresses, consumption of addictive goods entails more and more severe deterioration of human capital of consumers. There is an inverse relationship between the value of the human capital and the costs incurred by the alcohol consumer.

2. Consumption of addictive goods and its negative consequences is determined by a range of economic, social, psychological, cultural and other factors, which vary considerably across regions and countries. Such regional variation of factors shapes the regional consumption patterns.

3. There is a great variety of indicators that can be used for assessment of the degree of human capital deterioration resulting from alcohol consumption. Their choice depends on the research goals and availability of reliable statistical data. For our study we chose a set of indicators that are regularly monitored on the national and regional level in Russia and that reflect the direct influence of alcohol consumption on human capital.

4. Our analysis based on the proposed set of indicators has shown that there are considerable regional variations in terms of human capital deterioration. Regions with higher income levels and those where religion plays an important role tend to be in a more favorable position than others. What causes more serious concern is that the group of lagging regions is quite large and includes 12 regions. The highest concentration of such regions is found in the Far Eastern and North-Western federal districts. These are peripheral, economically disadvantaged areas. 
5. Our findings can be useful for devising and implementing regional policies aimed to curb consumption of goods with health risks. Such policies should focus on alcoholism prevention at the stages of family and community socialization and socialization in the schooling process. It should be noted, however, that, to achieve a long-term effect, such policies require stable macro-economic conditions and equalization of regional disparities.

\section{References}

1. Becker, G.S., \& Murphy, K.M. (1988). A Theory of Rational Addiction. Journal of Political Economy, 96, 4, 675-700. Retrieved from: https://pdfs.semanticscholar.org/ebf3/f79cd5e3795db374d715206b83deee4057db.pdf.

2. Edwards, G. (1994). Alcohol policy and the public good. Oxford: Oxford University Press.

3. Gruber, J. (2001) Tobacco at the Crossroads: The Past and Future of Smoking Regulation. Journal of Economic Perspectives, 15(2), 193-212. doi: 10.1257/jep.15.2.193.

4. Koch, J.V., \& Group, S.E. (1980). The Economics of Drug Control Policies. In The Economics of Crime. Cambridge (Mass.), pp. 339-350.

5. Kim, V.V., \& Roshchin, S.Yu. (2011). Influence of Alcohol Consumption on Employment and Wages in Russia. Ekonomicheskii zhurnal vysshei shkoly ekonomiki = HSE Economic Journal, 15(1), 3-33. (In Russ) Retrieved from: https://ej.hse.ru/2011-15-1/38503167.html.

6. Kim, V.V., \& Roshchin, S.Yu. (2009). The Influence of Alcohol Consumption on Wages. Moscow: Higher School of Economics. (In Russ.) Retrieved from: https://www.hse.ru/data/824/975/1240/ WP15 2009 01.pdf.

7. Becker, G. (2003) Human behavior: an economic approach. Moscow: Higher School of Economics. (In Russ.)

8. Wagstaff, A., \& Maynard, A. (1998). Economic Aspects of the Illicit Drug Market and Drug Enforcement Policies in the United Kingdom: Summary of the Reporf. British Journal of Addiction, $84,461-475$.

9. Chaloupka, F.J., \& Warner, K.E. (2000). The economics of smoking. In Culyer, A J., Newhouse, J.P. (Eds.) Handbook of health economics (Vol. 1, pp. 1539-1627). North Holland.

10. Gieringer D. (2015). Economic analysis of the legalization of cannabis. Ekonomicheskaya teoriya prestuplenii $i$ nakazanii $=$ The economic theory of criminal and law enforcement, 1. (In Russ.) Retrieved from: http://corruption.rsuh.ru/magazine/3/n3-16.shtml.

11. Chaloupka, F.J., Grossman, M., \& Tauras, J.A. (1999). The Demand for Cocaine and Marijuana by Youth. In Chaloupka, F.J., Grossman, M., Bickel, W.K., Saffer, H. (Eds.) The Economic Analysis of Substance Use and Abuse: An Integration of Econometrics and Behavioral Economic Research (pp. 133-155). University of Chicago Press. Retrieved from: https://www.nber.org/chapters/ c11158.pdf.

12. Baltagi, B.H., \& Griffin, J.M. (2002). Rational addiction to alcohol: panel data analysis of liquor consumption. Econometrics and Health Economics, 11, 485-491. doi: 10.1002/hec.748.

13. Wangen, K. (2004) Some Fundamental Problems in Becker, Grossman and Murphy's Implementation of Rational Addiction Theory. Discussion Papers, 375. Retrieved from: http://www.ssb. no/a/publikasjoner/pdf/DP/dp375.pdf.

14. Clarke, H., \& Danilkina, S. (2006). Talking Rationally About Rational Addiction. In Bloch, H., MacDonald, G. (ed.), Proceedings of the 35th Australian Conference of Economists, September 25-27, 2006 (pp. 1-29). Bentley, WA: Economic Society of Australia. Retrieved from: https://pdfs.semanticscholar.org/b871/85dbf86e25b67a0446155d2c5c10917c6a94.pdf? $\mathrm{ga}=2.128088649 .433560166 .1588444133-2012377774.1577261936$.

15. Gordon, B.R., \& Sun, B. (2015). Dynamic Model of Rational Addiction: Evaluating Cigarette Taxes. Marketing Science, 34(3), 309-472. doi: 10.1287/mksc.2014.0885.

16. Evans, D.G. (2013). The Economic Impacts of Marijuana Legalization. Journal of Global Drug Policy and Practice, 7(4), 2-40. Retrieved from: https://pdfs.semanticscholar.org/ a465/e5c83e83e2bd0acf781beae1183266ac856b.pdf? ga $=2.165892347 .433560166 .1588444133$ 2012377774.1577261936. 
17. Bukin, K., Levin, M., \& Shilova, N. (2016). Choice of addictive behavior: Temptation, risks, and self-control. Voprosy Ekonomiki, 12, 104-128. (In Russ.) doi: 10.32609/0042-8736-2016-12-104-128.

18. Filippov, K.V. (2018). Modeling addictive behavior. (In Russ.) Retrieved from: www.econorus. org/consp/files/nljx.doc.

19. Ponomareva, M.S. (2012). The problem of excessive alcohol consumption from the point of view of microeconomic theory: On the necessity of state interference. Problemy sovremennoi ekonomiki $=$ Problems of Modern Economics. 2, 477-479. (In Russ.) Retrieved from: http://www.m-economy.ru/art.php?nArtId=4148.

20. Keselman, L., \& Matskevich M.G. (2013). The social space of narcotism. Drug Business, 8, 62. (In Russ.)

21. English, D.R., Holman, C.D.J., Milne, E., Winter, M.G., Hulse, G., Codde, J.P. et al. (1995). The quantification of drug caused morbidity and mortality in Australia. Canberra: Commonwealth Department of Human Services and Health.

22. Keselman, L.E., Matskevich, M.G., \& Timofeev, L.M. (2001). Social space of drug addiction. The drug business. The initial theory of the economic sector, $2^{\text {nd }}$ ed. St. Petersburg: Meditsinskaya pressa. (In Russ.)

23. Podberezkin, A.I. (2013). GDP growth rates and human capital. (In Russ.) Retrieved from: http://mgimo.ru/about/news/experts/242193/.

24. Tereshchenkova E. (2013). Narcologist: «Women are getting addictive faster than men» (2013). Argumenty i fakty = Arguments and Facts, October 4. (In Russ.) Retrieved from: http://www. smol.aif.ru/health/938253.

25. Grechanaya, T.B. (ed.) (2014). Practical manual on the organization of the program of prevention of alcohol and drug abuse at enterprises. (In Russ.) Retrieved from: https://docplayer. $\underline{\mathrm{ru} / 58603244 \text {-Prakticheskoe-posobie-po-organizacii-programmy-profilaktiki-zloupotrebleniya-alk- }}$ ogolem-i-narkotikami-na-predpriyatiyah.html.

26. Kazarinova, D.B. (2017). Educational-methodical complex of the discipline (course) «Managing human capital». (In Russ.) Retrieved from: http://web-local.rudn.ru/web-local/prep/rj/index. php?id=3319\&mod=disc\&disc $\_$id=6278\&disc $\_$razdel $=43941 \& p=-1$.

27. Loveland-Cherry, C. J. (2005) Alcohol, children, and adolescents. Annual Review of Nursing Research, 23(1), 135-177. doi: 10.1891/0739-6686.23.1.135.

28. Cook, P. J., \& Moore, M. J. (1993). Drinking and schooling. Journal of Health Economics, 12(4), 411-429. doi: 10.1016/0167-6296(93)90003-W.

29. Andreev, E.M., \& Zbarskaya, I.A. (2009). Statistics of mortality in Russia from the causes of alcohol etiology. Voprosy statistiki, 8, 44-50. (In Russ.) Retrieved from: https://elibrary.ru/item. asp?id=22472794.

30. Grigoryev, V., \& Zeitlin, Yu. (2017) Drug use and HIV infection. (In Russ.) Retrieved from: http://narcom.ru/publ/info/814.

31. Stenbacka, M., Leifman, A., \& Romelsjö, A. (2010) Mortality and cause of death among 1705 illicit drug users: a 37 year follow up. Drug and Alcohol Review, 29(1), 21-27. doi: 10.1111/j.14653362.2009.00075.x.

32. Danishevsky, K. (2006). The demographic crisis in Russia: optimal ways to overcome it. Otechestvennye zapiski, 29(2), 50-62. (In Russ.)

33. Korotaev, A., \& Khalturina, D. (2006). Russian Vodka Cross. Ekspert, 17, 72-78. (In Russ.) Retrieved from: http://alcomarket.info/CRNAP/print.asp?NewsId=48474.

34. Podlazov, A.V. (2013). Modernization of mortality in Russia. Alcohol and Reforms. (In Russ.) Retrieved from: http://demoscope.ru/weekly/2006/0265/analit02.php.

35. Shinkevich, M.V., \& Malysheva, T.V. (2016). Improving the mechanisms of regulation of scientific and innovative activities at the regional level. Vestnik Belgorodskogo universiteta kooperatsii, ekonomiki i prava = Herald of the Belgorod University of Cooperation, Economics and Law, 5, 142-151. (In Russ.)

36. Pletnev, D.A., \& Nikolaeva, E.V. (2016). Contradictions of human potential as a key success factor of small and medium-sized businesses. Upravlencheskie nauki v sovremennom mire $=$ 
Management Sciences in the Modern World, 1, 70-74. (In Russ.) Retrieved from: https://elibrary.ru/ item.asp?id=28829890.

37. Valenčík R., Sazanova S., Yerznkyan B., Ryazanova G. Productive consumption and economic communications. Putevoditel predprinimatelya = Entrepreneur's Guide, 13(1), 118-129. (In Russ.) doi: 10.24182/2073-9885-2020-13-1-118-129.

\section{Information about the author}

Roman Yu. Skokov - Doctor of Economics, Professor, Volgograd State Agrarian University (26 Universitetsky av., Volgograd, 400002, Russia); e-mail: rskokov@mail.ru

Olga V. Brizhak - Doctor of Economics, Professor, State University of Management (109542, 99 Ryazansky av., Russia, Moscow), Kuban State Technological University (2 Moskovskaya Str., 350072, Krasnodar, Russia); e-mail: brizhak71@mail.ru

ARTICLE INFO: received January 23, 2020; accepted March 12, 2020

\section{Информация об авторах}

Скоков Роман Юрьевич - доктор экономических наук, профессор, Волгоградский государственный аграрный университет (400002, Россия, г. Волгоград, пр-кт Университетский, 26); e-mail: rskokov@mail.ru

Брижак Ольга Валентиновна - доктор экономических наук, профессор Государственный университет управления (109542, Россия, г. Москва, Рязанский пр., 99); Кубанский государственный технологический университет (350072, Россия, г. Краснодар, ул. Московская, 2); e-mail: brizhak71@mail.ru

ИНФОРМАЦИЯ О СТАТЬЕ: дата поступления 23 января 2020 г.; дата принятия к печати 12 марта 2020 г. 